\title{
BRAZING OF TITANIUM WITH ALUMINIUM ALLOYS
}

\begin{abstract}
This study presents results of vacuum diffusion brazing of Grade 2 titanium with 6082 (AlMg1Si0.6Cu0.3) aluminium alloy using B-Ag72Cu-780 (Ag72Cu28) grade silver brazing metal as an interlayer. Brazed joints underwent shear tests, light-microscopybased metallographic examinations and structural examinations using scanning electron microscopy (SEM) and X-ray energy dispersive spectrometry (EDS). The highest quality and shear strength of $20 \mathrm{MPa}$ was characteristic of joints brazed at $530^{\circ} \mathrm{C}$ with a 30-minute hold. The structural examinations revealed that in diffusion zone near the boundary with titanium the braze contained solid solutions based on hard and brittle Ti-Al type intermetallic phases determining the strength of the joints.
\end{abstract}

Keywords: titanium, aluminium alloy, diffusion brazing, mechanical properties of brazing joints, brazing parameters

\section{Introduction}

Advantageous mechanical properties, low density and excellent corrosion resistance make titanium, and its alloys, very attractive structural materials for many demanding applications in modern industries. However, in spite of being fairly common in the earth crust, due to its high reactivity and difficult obtainment, titanium is characterised by a relatively high price. For this reason, in many applications some structural elements and components made of titanium are partly replaced by those made of cheaper stainless steels or aluminium and its alloys. In the latter case it is also possible to additionally obtain the reduction of a structure weight. A primary condition formulated by design engineers in relation to such structural systems used in the production of tooling, automotive industry, aviation, electronics, production of equipment and heat exchangers in chemical industry is the possibility of joining the aforesaid materials using welding methods and ensuring good operational properties of joints $[1,4,8,10,14]$.

Joining titanium and aluminium and their alloys by means of welding methods is fairly difficult due to different physicochemical properties (fusibility, thermal conductivity and expansion, reactivity with gases present in the environment) as well as due to the formation of brittle intermetallic phases in the heat affected zone. Methods recommended for making such joints include few specialist fusion welding methods (electron beam welding, laser welding), pressure welding methods (diffusion welding, friction welding) and diffusion brazing [8-15]. Few available publications concerned with diffusion brazing indicate that the issue is still at the stage of laboratory tests [13-15]. No such tests have been conducted in Poland until today.
This publication presents results of tests focused on diffusion brazing of titanium with aluminium alloys conducted at Instytut Spawalnictwa in Gliwice. The research-related tests presented in the article are the continuation of previously conducted research related to brazing titanium with other metals [16-18].

\section{Diffusion brazing of titanium with tluminium and its tlloys}

Diffusion brazing is described as a brazing method in which diffusion is decisive for the chemical composition and physical properties of a braze. The braze is formed using a brazing metal supplied from the outside or created as a phase of lower fusibility due to diffusion interaction taking place at the interface of elements joined with each other or with an intermediate layer placed between these elements (coating, interlayer). Diffusion brazing, also referred to as TLP bonding (transient liquid phase bonding) takes place at a temperature above $500 \div 800^{\circ} \mathrm{C}$ [2-5].

In the case of diffusion brazed joints made without a brazing metal supplied from the outside, the formation mechanism is based on a "reactive melting" phenomenon and involves metals (materials) forming phase systems with eutectics or with a continuous solid solution having a "minimum" on a liquidus line. This is also possible for alloys, the components of which have the properties mentioned above or after applying coatings or interlayers made of materials meeting the conditions presented above. This eutectic or a solid solution of a "minimum" composition, i.e. a phase of lower fusibility than the fusibili- 
ties of reacting components, constitutes a brazing metal during a brazing process. This method is used, among other things, for joining titanium with aluminium (titanium alloys and aluminium) $[2,5]$.

The basic physico-chemical properties of these metals are presented in Table $1[1,3-5]$. It should be noted that a titaniumaluminium material system (titanium alloys-aluminium alloys) belongs to hard-to-braze systems due to significantly varying fusibilities of materials being joined (limited selection of brazing metals), very stable oxide layers (not wettable by brazing metals) strictly adhering to material surfaces, high reactivity of titanium with almost all metals and gases and the formation of hard and brittle intermetallic phases (in brazes) leading to the deterioration of mechanical properties of brazed joints [2-5]. While diffusion brazing a titanium-aluminium system, due to a fairly low aluminium fusibility (melting point of $660^{\circ} \mathrm{C}$, and respectively lower in the case of alloys) it is necessary to use relatively low process temperatures (below $600^{\circ} \mathrm{C}$ ), which is inconvenient for obtaining a proper course of diffusion.

TABLE 1

Basic physico-chemical properties of aluminum and titanium $[1,2]$

\begin{tabular}{|c|l|c|c|}
\hline \hline No. & \multicolumn{1}{|c|}{ Properties } & Aluminium & Titanium \\
\hline 1 & Melting point, ${ }^{\circ} \mathrm{C}$ & 660 & 1668 \\
\hline 2 & Density, $\mathrm{kg} / \mathrm{dm}^{3}$ & 2.7 & 4.05 \\
\hline 3 & $\begin{array}{l}\text { The coefficient of linear thermal } \\
\text { expansion, } 1 / \mathrm{K} \text { in temp. } 0-1000^{\circ} \mathrm{C}\end{array}$ & $(24-33) \times 10^{-6}$ & $(7-12) \times 10^{-6}$ \\
\hline 4 & Thermal conductivity, $\mathrm{W} / \mathrm{m} \times \mathrm{K}$ & $200-240$ & 22.6 \\
\hline 5 & Tensile strength, $\mathrm{MPa}$ & $90-120$ & $500-700$ \\
\hline 6 & $\begin{array}{l}\text { Energy forming oxides } \\
\text { (enthalpy), } \mathrm{kJ} / \mathrm{molO}_{2}\end{array}$ & $\mathrm{Al}_{2} \mathrm{O}_{3} / 1116.2$ & $\mathrm{TiO}_{2} / 916.9$ \\
\hline
\end{tabular}

Available specialist reference publications mention very few cases of research-related tests dedicated to this issue. They mainly refer to joining Al 1050 grade aluminium with $\mathrm{CP}-\mathrm{Ti}$ grade titanium using AlSi10Mg1 alloy as an interlayer [14] as well as to joining TiAl6V4 grade titanium with Al 7075 grade aluminium using pure copper [15] and copper and Sn-Ag-Bi alloy [16] as interlayers. The authors presented the results of shear tests and structural tests of joints as well as indicated the most convenient temperature-time brazing parameters in terms of joint quality and strength.

It should be emphasized that the strength of brazed joints made of titanium and other metals is influenced by the presence of intermetallic phases of a so-called incongruent fusibility (the phase does not exist in a liquid state if the concentration of components corresponds to the chemical composition of the phase), usually in the form of continuous layers, often formed as a result of a peritectic reaction. A clearly negative effect on the strength of joints is characteristic of hard and brittle intermetallic phases with titanium such as Ti-Cu, Ti-Fe (Ti-Fe-Cr, Ti-Fe-Ni), $\mathrm{Ti}-\mathrm{Ni}$, Ti-Cr and Ti-Al and well as solid solutions based on these phases. The lowest brittleness and hardness were characteristic of Ti-Ag type phases, which was also determined in tests previously conducted at Instytut Spawalnictwa and dedicated to the kinetics of the formation of intermetallic phases and their effect on the operational properties of brazed joints made of titanium and stainless steel using silver brazing metals [17,18].

\section{Test results}

\subsection{Materials used in tests}

The tests involved the use of base materials in the form of cylindrical specimens (cut out of bars) $(\varnothing 20 \times 15 \mathrm{~mm})$ made of Grade 2 titanium according to ASTM B348 and AW-6082 (AlMg1Si0.6Cu0.3) grade aluminium alloy according to PN-EN 573-3:2014. Tables 2 and 3 present the chemical compositions of these materials. The chemical composition of the materials was analysed using a Bruker-manufactured Q4 TASMAN spark emission spectrometer.

The interlayer used for making brazed joints was Ag 272 (B-Ag72Cu-780) grade silver brazing metal according to PN-EN ISO 17672:2010, having a mass chemical composition according to analysis: $72.45 \% \mathrm{Ag}$, the rest: $\mathrm{Cu}$ (0.05 mm thick strip). Selecting an $\mathrm{Ag}-\mathrm{Cu}$ type filler metal as the interlayer aimed to reduce the amount of $\mathrm{Al}-\mathrm{Cu}$ and $\mathrm{Ti}-\mathrm{Cu}$ hard phase precipitates in joints by partly replacing them with more plastic and less hard phases containing Ag.

TABLE 2

The results of chemical analysis of aluminium alloy AW-6082

\begin{tabular}{|l|c|c|c|c|c|c|c|c|c|}
\hline \hline \multirow{2}{*}{ Type of material } & \multicolumn{9}{c|}{ The content of elements, \% wt. } \\
\cline { 2 - 10 } & $\mathbf{M g}$ & $\mathbf{M n}$ & $\mathbf{F e}$ & $\mathbf{S i}$ & $\mathbf{C u}$ & $\mathbf{Z n}$ & $\mathbf{C r}$ & $\mathbf{T i}$ & $\mathbf{A l}$ \\
\hline AW-6082, acc. PN-EN 573-3:2014 & $0.60-1.20$ & $0.40-1.00$ & $\leq 0,50$ & $0.70-1.30$ & $\leq 0.10$ & $\leq 0.20$ & $\leq 0.25$ & $\leq 0.10$ & rest \\
\hline $\begin{array}{l}\text { Aluminium alloy AW-6082 acc. } \\
\text { chemical analysis (used in the tests) }\end{array}$ & 1.06 & 0.842 & 0.254 & 0.962 & 0.004 & 0.091 & 0.102 & 0.001 & 96.73 \\
\hline
\end{tabular}

TABLE 3

The results of chemical analysis of titanium Grade 2

\begin{tabular}{|l|c|c|c|c|c|c|}
\hline \hline \multirow{2}{*}{ Type of material } & \multicolumn{5}{c|}{ The content of elements, \% wt. } \\
\cline { 2 - 7 } & $\mathbf{F e}$ & $\mathbf{O}$ & $\mathbf{N}$ & $\mathbf{C}$ & $\mathbf{H}$ & $\mathbf{T i}$ \\
\hline Grade 2 acc. ASTM B265 & $\leq 0.30$ & $\leq 0.25$ & $\leq 0.03$ & $\leq 0.10$ & $\leq 0.015$ & rest \\
\hline Grade 2 acc. chemical analysis (used in the tests) & 0.051 & not determined & not determined & $<0.002$ & not determined & 99.86 \\
\hline
\end{tabular}




\subsection{Adjustment of brazing parameters and making test joints}

Shear tests and structural tests of diffusion brazed joints involved using butt brazed cylindrical specimens $(\varnothing 20 \times 15$ $\mathrm{mm}$ ). Such a specimen type enabled the economical disposal of base materials and filler metals. The use of appropriate tooling during strength tests enabled the obtainment of pure shearing and favoured an uninterrupted course of diffusion processes in a braze, ensuring high joint repeatability [16-19]. Directly before brazing, elements to be joined underwent chemical etching.

Ag 272 (B-Ag72Cu-780) grade silver-copper filler metal used during brazing as an interlayer was prepared in the form of shapes having diameters corresponding to those of elements to be joined and placed in an amount enabling the obtainment of a $0.1 \mathrm{~mm}$ thick layer ( 2 shapes/joint), between elements being joined, with aluminium being at the bottom and titanium at the top.

All the specimens were brazed in a TORVAC-manufactured $\mathrm{S} 16$ vacuum furnace in a vacuum ranging from $10^{-4}$ to $10^{-5} \mathrm{mbar}$. The rate of heating the specimen up to a brazing temperature amounted to $30-40^{\circ} \mathrm{C} / \mathrm{min}$. During brazing, the temperature of specimens was controlled by means of a Pt-PtRh13 type contact thermocouple (vacuum furnace equipment element). The adjustment of a diffusion brazing temperature and time (generally dependent on types of materials being joined and on an interlayer) was determined on the basis of the thorough analysis of information available in reference publications [3-5,13-15] and following the analysis of appropriate $\mathrm{Al}-\mathrm{Ag}, \mathrm{Al}-\mathrm{Cu}$ and $\mathrm{Ti}-\mathrm{Ag}$, and $\mathrm{Ti}-\mathrm{Cu}$ type phase equilibrium systems $[1,6,7]$. The parameters were as follows: a brazing temperature of $520-580^{\circ} \mathrm{C}$ and a hold time of 15,30 and $60 \mathrm{~min}$.

In accordance with the expected mechanism of brazed joint formation, the filler metal formed in titanium-aluminium type joints (as a result of diffusion), made using an $\mathrm{Ag}-\mathrm{Cu}$ type silver filler metal as an interlayer, should be constituted by a low-melting liquid phase composed of eutectics: Al-Ag (solid solution $\mathrm{Al}$-intermetallic phase $\mathrm{Ag}_{2} \mathrm{Al}$, a transformation point of $566^{\circ} \mathrm{C}$ ) and $\mathrm{Al}-\mathrm{Cu}$ (solid solution Al-intermetallic phase $\mathrm{CuAl}_{2}$, a transformation point of $548^{\circ} \mathrm{C}$ ) [6,7]. However, diagnostic tests revealed that the liquid phase constituting the filler metal in the brazing process appeared in the joint gap already at a temperature of $500-510^{\circ} \mathrm{C}$. The reduction of the liquid phase fusibility was undoubtedly caused by the fact that the phase was enriched in $\mathrm{Ti}$ as well as in $\mathrm{Si}$ and $\mathrm{Mg}$ coming from the aluminium alloy being joined.

Both components of the Ag-Cu type filler metal interlayer also form eutectics with titanium, yet their melting points are significantly higher and exceed $800^{\circ} \mathrm{C}$. Therefore, they cannot constitute the filler metal in this process.

Brazing tests made with the process parameters described above have shown the most favorable quality for joints brazed at a temperature of $530-550^{\circ} \mathrm{C}$ and a hold time of $30 \mathrm{~min}$. These joints showed no brazing imperfection (visual and macrometallographic tests). In other cases, at lower temperatures and holding time occurred bonding imperfections in joints and at higher temperatures and longer times there were few gas cavities and leak of the liquid phase out of the joint.

\subsection{Shear strength of test brazed joints}

The shear strength of brazed cylindrical specimens made of Grade 2 titanium with AW-6082 aluminium alloy was tested using a testing machine manufactured by the Instron company (model 4210). The specimens were placed in special holders designed in a manner making it possible for the specimens to be subjected to shear forces only, without bending. Previous own research and information contained in reference publications indicate that a shear test performed in such a manner is advantageous for dissimilar joints, forming brittle intermetallic phases with the filler metal [16-19].

The shear tests were performed for three specimens for each temperature-time brazing process variant. The tests results for selected test joints, after statistical processing, are presented in Table 4. During shearing the specimens ruptured on the titanium side.

The strength tests revealed that the test joints brazed in the tested range of temperature-time parameters slightly differed in their strength. The highest shear strength of approximately $20 \mathrm{MPa}$ was obtained for the joints brazed at a temperature of $530^{\circ} \mathrm{C}$ and $30 \mathrm{~min}$ hold time. It was also determined that an increase in a brazing temperature and in a hold time was accompanied by a slight decrease in shear strength.

TABLE 4

Shear strength of selected titanium Grade 2-aluminium alloy AW-6082 joints, diffusion brazed using $\mathrm{Ag} 72 \mathrm{Cu} 28$ filler metal as an interlayer

\begin{tabular}{|c|c|c|c|c|}
\hline \multirow[b]{2}{*}{ No. } & \multirow[b]{2}{*}{$\begin{array}{c}\text { Brazing } \\
\text { temperature, }{ }^{\circ} \mathrm{C}\end{array}$} & \multirow{2}{*}{$\begin{array}{l}\text { Hold time, } \\
\text { min }\end{array}$} & \multicolumn{2}{|c|}{ Shear strength, MPa } \\
\hline & & & $\begin{array}{c}\text { Average } \\
\text { value* }\end{array}$ & $\begin{array}{l}\text { Standard } \\
\text { deviation }\end{array}$ \\
\hline 1 & 530 & 30 & 20.05 & 1.98 \\
\hline 2 & 530 & 60 & 19.11 & 1.25 \\
\hline 3 & 550 & 30 & 18.63 & 1.75 \\
\hline 4 & 580 & 60 & 17.98 & 1.25 \\
\hline
\end{tabular}

* - the average value of 3 measurements

\subsection{Structural tests of brazed joints}

The structural tests of the diffusion brazed joints made of Grade 2 titanium and AW-6082 (AlMg1Si0.6Cu0.3) aluminium alloy, using a B-Ag72Cu-780 filler metal interlayer, were performed using a Leica-manufactured MeF4A light microscope as well as a Hitachi S-3400N scanning electron microscope (SEM) collaborating with a Thermo Noran System Six X-ray energy dispersive spectrometer (EDS).

The tests involving the use of a light microscope had a quality character and enabled assessing the quality of joints and the initial identification of their structures (level of complexity, 

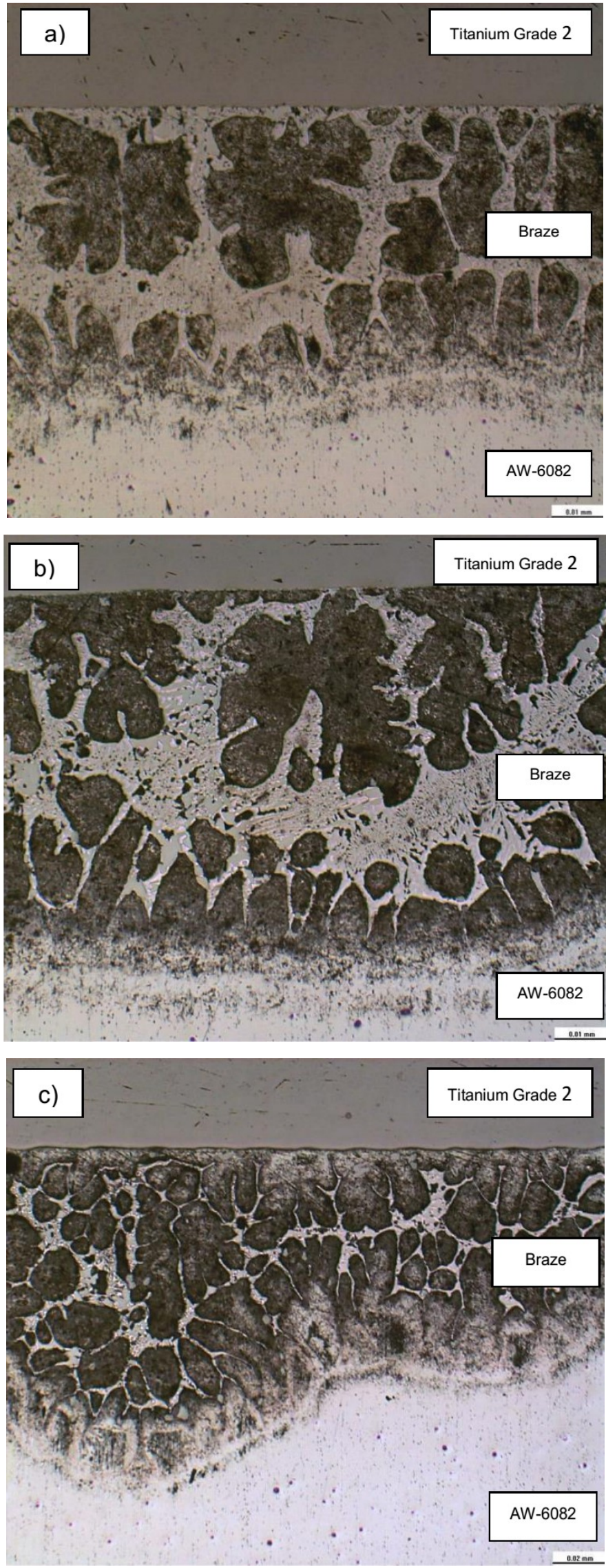

Fig. 1. Microstructure of diffusion brazed joints made of Grade 2 titanium and $\mathrm{AW}-6082$ aluminium alloy, using $\mathrm{Ag} 72 \mathrm{Cu} 28$ filler metal a) at a temperature of $530^{\circ} \mathrm{C}$ and a hold time of $30 \mathrm{~min} \mathrm{~b}$ ) at a temperature of $550^{\circ} \mathrm{C}$ and a hold time of $30 \mathrm{~min} \mathrm{c}$ ) at a temperature of $580^{\circ} \mathrm{C}$ and a hold time of $60 \mathrm{~min}$ appearance, shape and phase arrangement). Figure 1 presents selected structures of joints made at various temperatures and for various brazing times.

The metallographic tests revealed a relatively good quality of joints as regards diffusion brazed joints. The specimens brazed at higher temperatures and for longer hold times contained few voids (Fig. 2), the formation of which can probably be ascribed to the Kirkendall effect. These specimens also revealed a slight escape (Fig. 3) of a liquid phase (formed due to diffusion in excess) having a melting point lower than those of elements joined, thus constituting a filler metal in a brazing process. The leakage accumulated at the base of the lower element of the cylindrical specimen, with the liquid phase spreading over the bottom surface of this element.

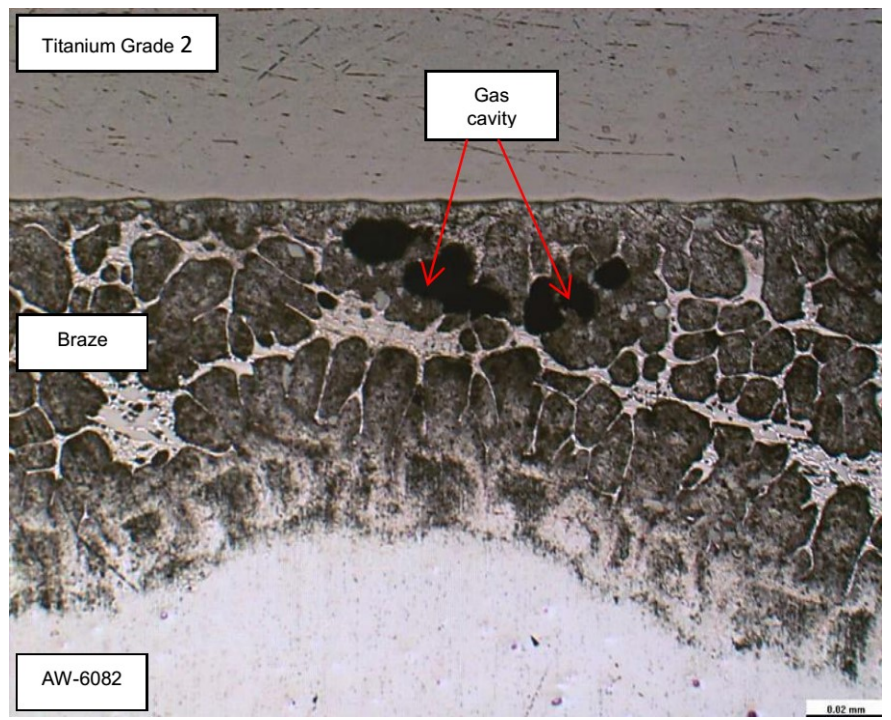

Fig. 2. Voids imperfections in a diffusion brazed joint made of Grade 2 titanium and AW-6082 aluminium alloy, using Ag72Cu28 filler metal at a temperature of $580^{\circ} \mathrm{C}$ and a hold time of $60 \mathrm{~min}$.

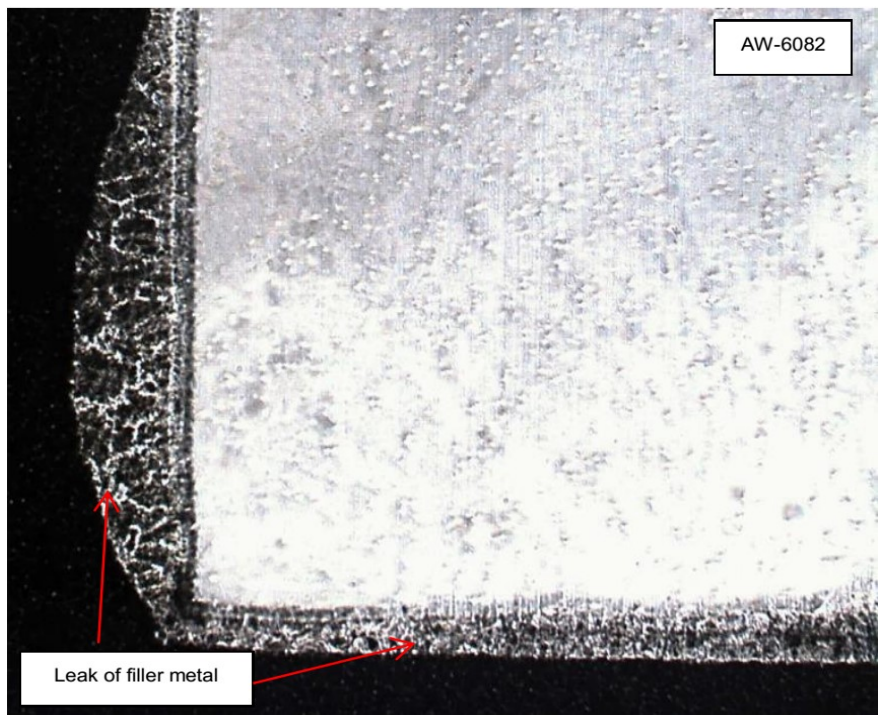

Fig. 3. Escape of the liquid phase (formed due to diffusion) from the gap of a diffusion brazed joint made of Grade 2 titanium and AW-6082 aluminium alloy, using $\mathrm{Ag} 72 \mathrm{Cu} 28$ filler metal at a temperature of $580^{\circ} \mathrm{C}$ and a hold time of $60 \mathrm{~min}$. 
The results of structural tests involving the use of a scanning electron microscope and an X-ray energy dispersive spectrometer (EDS) are presented in Figures 4-7.

In the case of diffusion brazed joints made in temperature of $530^{\circ} \mathrm{C}$ and a hold time of $30 \mathrm{~min}$, the braze revealed a relatively complex structure. Its central part (Fig. 4) contained Al-Cu-Ti-Si, Al-Ag-Ti-Si and Si-Al-Ti-Ag type solid solutions of diversified chemical compositions and forms (globular, polygonal, acicular and laminar precipitates), also based on $\mathrm{CuAl}_{2}$ and $\mathrm{Ag}_{2} \mathrm{Al}$ intermetallic phases. Some of these phases formed eutectics. Near the boundary with titanium (Fig. 5) the braze contained solid solutions stoichiometrically corresponding to solutions based on hard and brittle $\mathrm{TiAl}_{3}$ and $\mathrm{Ti}_{3} \mathrm{Al}$ type intermetallic phases. It was in this area that the specimen ruptured during shear tests.

A similar morphological structure was characteristic of the joints made at higher brazing temperatures and with longer hold times e.g. at a temperature of $580^{\circ} \mathrm{C}$ and a hold time of 60 min-Fig. 6 . In the part of the braze near titanium the content of this chemical element in the aluminium-based solid solution increased significantly (Fig. 7a-c). The diffusion zones on the titanium side revealed more diversified precipitates of solid solutions on matrixes stoichiometrically corresponding to hard and brittle $\mathrm{CuAl}_{2}, \mathrm{Ag}_{2} \mathrm{Al}$, TiAl, $\mathrm{TiAl}_{3}$ and $\mathrm{Ti}_{5} \mathrm{Al}_{11}$ type intermetallic phases.

\section{Conclusions}

1) The most convenient temperature-time conditions while diffusion brazing Grade 2 titanium with 6082 (AlMg1Si0.6Cu0.3) aluminium alloy in a vacuum furnace, using B-Ag72Cu-780 (Ag72Cu28) grade silver filler metal interlayer, ensuring the obtainment of high quality and high shear strength $(20 \mathrm{MPa})$ of joints, include a brazing temperature of $530^{\circ} \mathrm{C}$ and a hold time of $30 \mathrm{~min}$.

2) Increasing a brazing temperature and extending a hold time reduces the strength of joints and their quality due to the formation of voids (Kirkendall effect) and the escape of the filler metal from the joining area.

3) The structural tests of the diffusion brazed joints, involving the use of scanning electron microscopy (SEM) and $\mathrm{X}$-ray energy dispersive spectroscopy (EDS) revealed the braze structure composed of solid solutions based on $\mathrm{Al}$, $\mathrm{Si}$ as well as on $\mathrm{CuAl}_{2}$ and $\mathrm{Ag}_{2} \mathrm{Al}$ intermetallic phases, of diversified chemical compositions and forms (globular, polygonal, acicular and laminar precipitates). Near the boundary with titanium the braze contained solid solutions stoichiometrically corresponding to solutions based on hard and brittle $\mathrm{TiAl}, \mathrm{Ti}_{5} \mathrm{Al}_{11}, \mathrm{Ti}_{3} \mathrm{Al}$ and $\mathrm{TiAl}_{3}$ type intermetallic phases determining the strength of the joints.

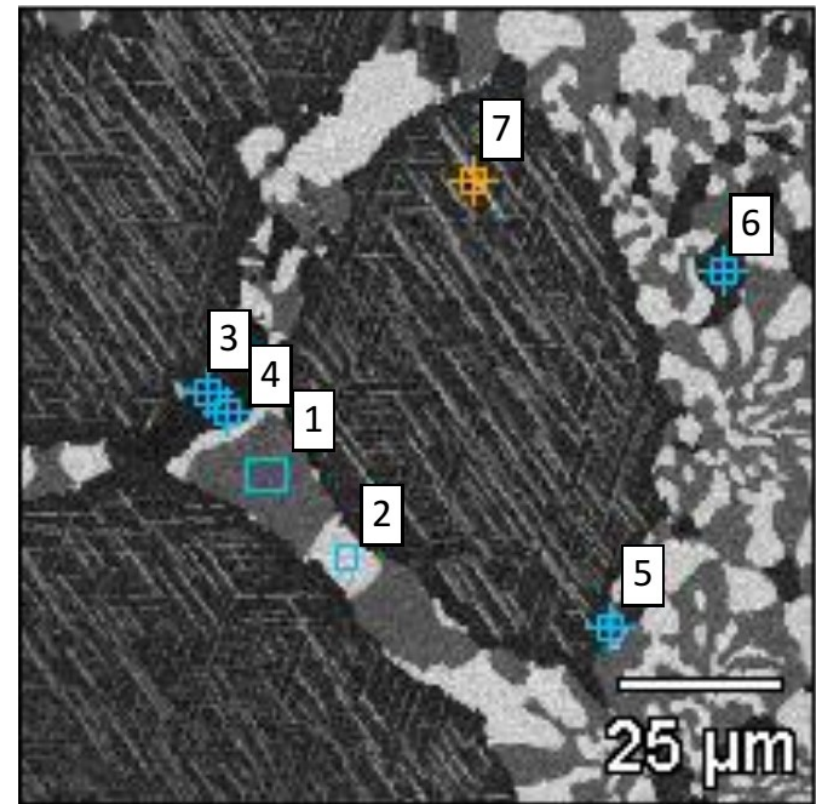

\begin{tabular}{|c|c|c|c|c|c|c|c|c|c|c|c|}
\hline \multirow{2}{*}{ Point } & \multicolumn{5}{|c|}{ Content, \% wt . } & \multicolumn{5}{|c|}{ Content, \% atomic } & \multirow{2}{*}{ Phase } \\
\hline & Al-K & Si-K & Ti-K & Cu-K & Ag-L & Al-K & Si-K & Ti-K & Cu-K & Ag-L & \\
\hline 1 & 51.1 & 1.1 & 12.2 & 26.4 & 9.2 & 70,4 & 1.5 & 9,5 & 15.5 & 3.2 & $\mathrm{CuAl}_{2}$ \\
\hline 2 & 30.7 & 0.4 & 10.2 & 0 & 58.7 & 59,6 & 0.7 & 11,1 & 0 & 28.5 & $\mathrm{Ag}_{2} \mathrm{Al}$ \\
\hline 3 & 23.5 & 55.1 & 12.3 & 0 & 9.1 & 27,5 & 61.8 & 8,1 & 0 & 2.7 & $\mathrm{Si}$ \\
\hline 4 & 70.4 & 2.0 & 13.6 & 0 & 13.9 & 84,3 & 2.4 & 9,2 & 0 & 4.2 & $\mathrm{Al}$ \\
\hline 5 & 43.4 & 0.4 & 9.4 & 0 & 46.8 & 71,4 & 0.7 & 8,7 & 0 & 19.2 & $\mathrm{Al}$ \\
\hline 6 & 66.8 & 0.4 & 10.5 & 0 & 22.2 & 84,9 & 0.5 & 7,5 & 0 & 7.1 & $\mathrm{Al}$ \\
\hline 7 & 50.5 & 0.5 & 11.9 & 0 & 37.1 & 75,4 & 0.7 & 10,0 & 0 & 13.9 & $\mathrm{Al}$ \\
\hline
\end{tabular}

Fig. 4. Fragment of the braze microstructure in a diffusion brazed joint made of Grade 2 titanium and AW-6082 aluminium alloy, using Ag72Cu28 filler metal interlayer, at a temperature of $530^{\circ} \mathrm{C}$ and a hold time of $30 \mathrm{~min}$, as well as the local analysis of phases (SEM-EDS) 


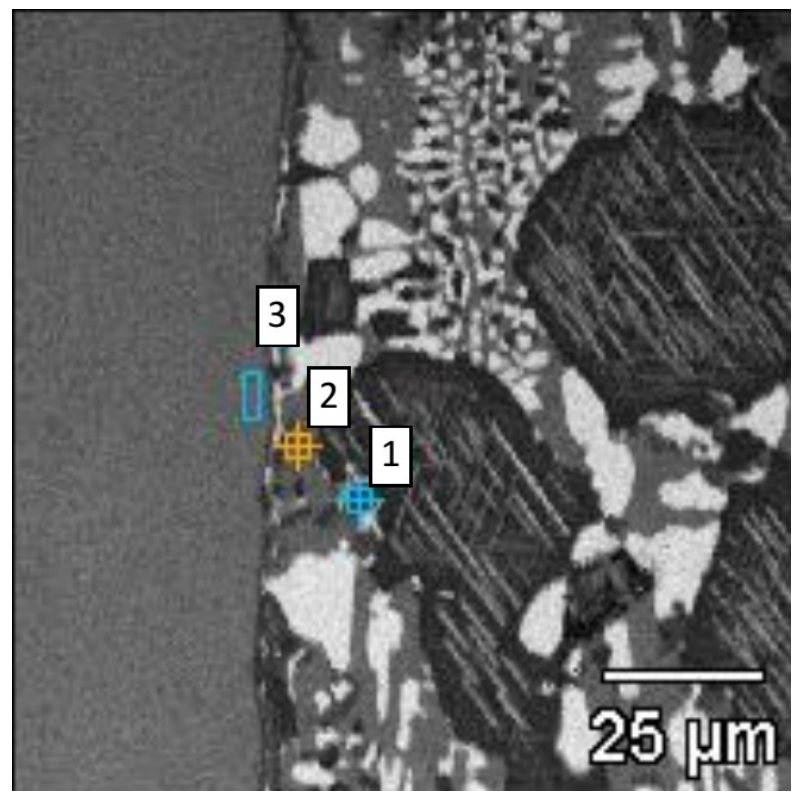

\begin{tabular}{|c|c|c|c|c|c|c|c|c|c|c|c|c|c|}
\hline \multirow{2}{*}{ Point } & \multicolumn{6}{|c|}{ Content, \% wt . } & \multicolumn{6}{|c|}{ Content, \% atomic } & \multirow[b]{2}{*}{ Phase } \\
\hline & Al-K & Si-K & Ti-K & Mn-K & Cu-K & Ag-L & Al-K & Si-K & Ti-K & Mn-K & Cu-K & Ag-L & \\
\hline 1 & 46.2 & 4.9 & 25.5 & 15.1 & 0 & 8.3 & 61.7 & 6.3 & 19.2 & 9.9 & 0 & 2.8 & $\mathrm{TiAl}_{3}$ \\
\hline 2 & 39.4 & 0.6 & 28.8 & 0 & 24.4 & 6.7 & 57.7 & 0.9 & 23.8 & 0 & 15.2 & 2.5 & $\mathrm{TiAl}_{3}$ \\
\hline 3 & 14.7 & 0.5 & 80.0 & 0 & 0 & 4.9 & 23.9 & 0.7 & 73.4 & 0 & 0 & 2.0 & $\mathrm{Ti}_{3} \mathrm{Al}$ \\
\hline
\end{tabular}

Fig. 5. Fragment of the microstructure (on the boundary with titanium) of a diffusion brazed joint made of Grade 2 titanium and AW-6082 aluminium alloy, using $\mathrm{Ag} 72 \mathrm{Cu} 28$ filler metal interlayer, at a temperature of $530^{\circ} \mathrm{C}$ and a hold time of 30 min as well as the local analysis of phases (SEM-EDS)

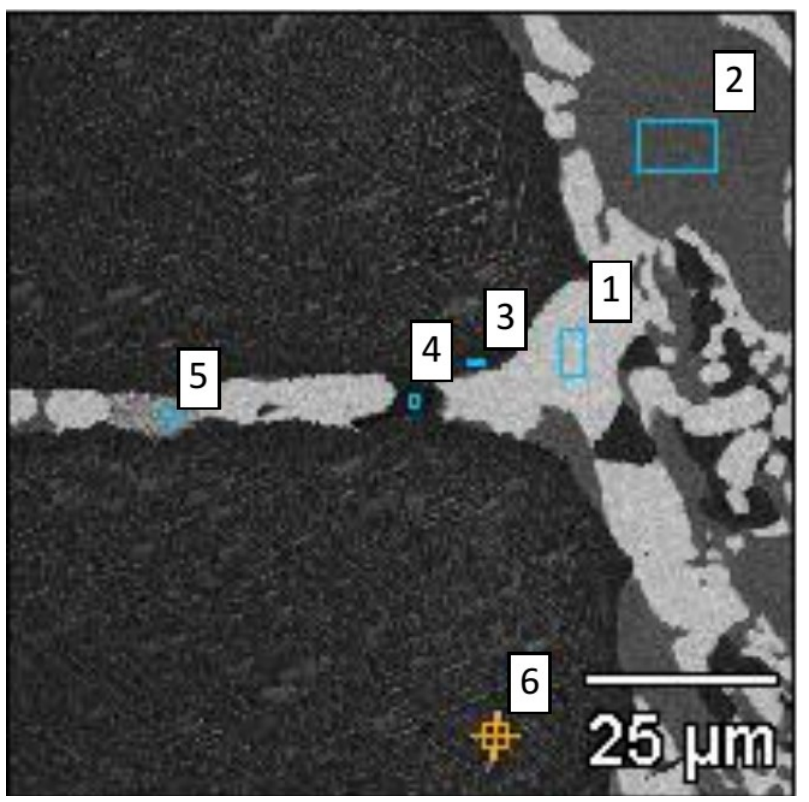

\begin{tabular}{|c|c|c|c|c|c|c|c|c|c|c|c|c|c|}
\hline \multirow{2}{*}{ Point } & \multicolumn{6}{|c|}{ Content, \% wt . } & \multicolumn{6}{|c|}{ Content, \% atomic } & \multirow{2}{*}{ Phase } \\
\hline & Mg-K & Al-K & Si-K & Ti-K & Cu-L & Ag-L & Mg-K & Al-K & Si-K & Ti-K & Cu-L & Ag-L & \\
\hline 1 & 1.5 & 23.0 & 0.4 & 1.2 & 3.3 & 70.7 & 3.7 & 51.4 & 0.8 & 1.5 & 3.1 & 39.5 & $\mathrm{Ag}_{2} \mathrm{Al}$ \\
\hline 2 & 0 & 54.9 & 1.0 & 2.0 & 33.2 & 8.9 & 0 & 74.9 & 1.4 & 1.5 & 19.2 & 3.0 & $\mathrm{Al}$ \\
\hline 3 & 0 & 71.1 & 0.7 & 1.7 & 5.1 & 21.3 & 0 & 88.6 & 0.9 & 1.2 & 2.7 & 6.6 & $\mathrm{Al}$ \\
\hline 4 & 0 & 18.4 & $66, .0$ & 1.6 & 1.8 & 12.3 & 0 & 21.3 & 73.3 & 1.1 & 0.9 & 3.5 & $\mathrm{Si}$ \\
\hline 5 & 2.4 & 33.0 & 0.5 & 1.7 & 10.0 & 52.4 & 4.9 & 60.6 & 0.9 & 1.8 & 7.8 & 24.1 & $\mathrm{Al}$ \\
\hline 6 & 0 & 57.7 & 0.5 & 1.5 & 4.3 & 35.9 & 0 & 82.6 & 0.7 & 1.2 & 2.6 & 12.9 & $\mathrm{Al}$ \\
\hline
\end{tabular}

Fig. 6. Fragment of the braze microstructure in a diffusion brazed joint made of Grade 2 titanium and AW-6082 aluminium alloy, using Ag72Cu28 filler metal interlayer, at a temperature of $580^{\circ} \mathrm{C}$ and a hold time of $60 \mathrm{~min}$ as well as the local analysis of phases (SEM-EDS) 


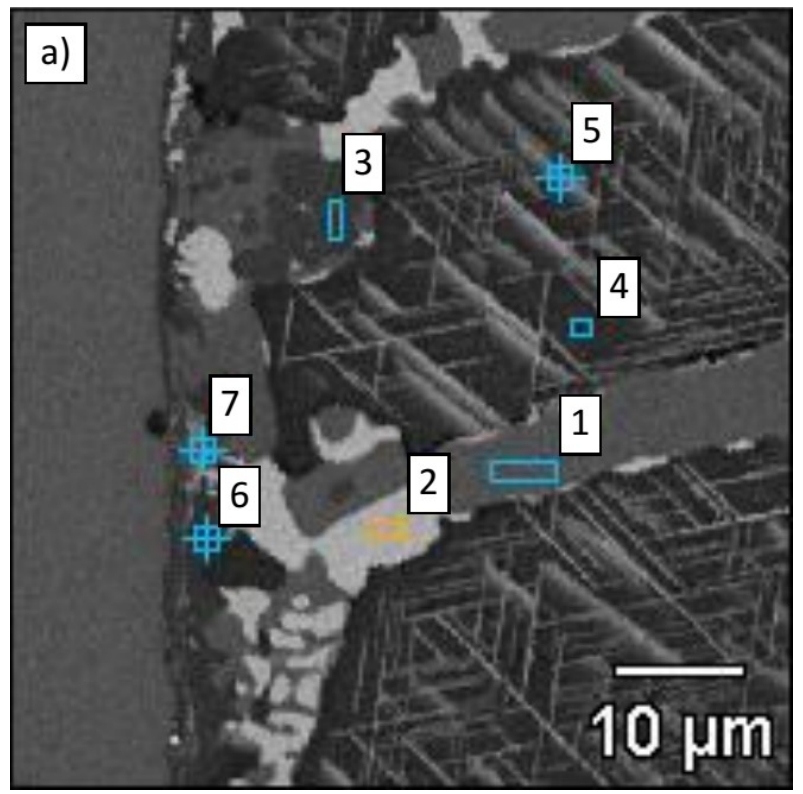

\begin{tabular}{|c|c|c|c|c|c|c|c|c|c|c|c|c|c|}
\hline \multirow{2}{*}{ Point } & \multicolumn{6}{|c|}{ Content, \% wt . } & \multicolumn{6}{|c|}{ Content, \% atomic } & \multirow{2}{*}{ Phase } \\
\hline & Al-K & Si-K & Ti-K & Mn-K & Cu-L & Ag-L & Al-K & Si-K & Ti-K & Mn-K & Cu-L & Ag-L & \\
\hline 1 & 43.6 & 0.4 & 12.3 & 0 & 37.5 & 6.2 & 63.7 & 0.5 & 10.2 & 0 & 23.3 & 2.3 & $\mathrm{CuAl}_{2}$ \\
\hline 2 & 17.3 & 0.2 & 11.7 & 0 & 3.6 & 67.2 & 40.8 & 0.5 & 15.5 & 0 & 3.6 & 39.6 & $\mathrm{Ag}_{2} \mathrm{Al}$ \\
\hline 3 & 50.0 & 6.9 & 14.7 & 19.8 & 3,5 & 5.0 & 64.6 & 8.6 & 10.7 & 12.6 & 1.9 & 1.6 & $\mathrm{Al}$ \\
\hline 4 & 67.9 & 0.1 & 11.9 & 0 & 4.6 & 15.5 & 84.3 & 0.1 & 8.3 & 0 & 2.4 & 4.8 & $\mathrm{Al}$ \\
\hline 5 & 53.0 & 0 & 11.6 & 0 & 4.6 & 30.8 & 76.6 & 0 & 9.5 & 0 & 2.8 & 11.1 & $\mathrm{Al}$ \\
\hline 6 & 46.2 & 4.7 & 42.9 & 0 & 1.5 & 4.7 & 60.2 & 5.9 & 31.5 & 0 & 0.8 & 1.5 & TiAl \\
\hline 7 & 25.9 & 2.2 & 28.2 & 0 & 4.4 & 39.4 & 46.5 & 3.9 & 28.6 & 0 & 3.3 & 17.7 & TiAl \\
\hline
\end{tabular}

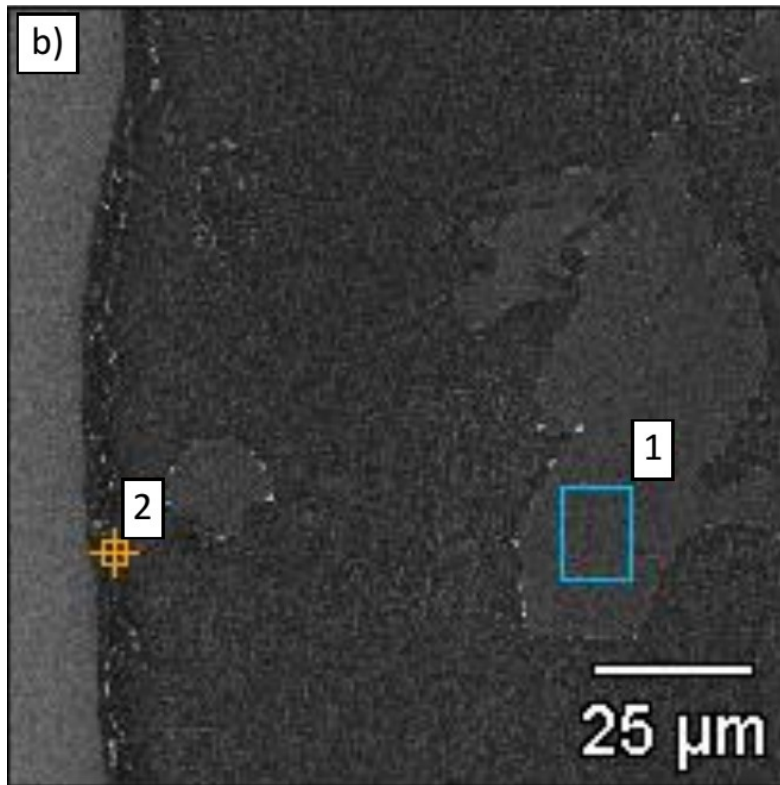

\begin{tabular}{|c|c|c|c|c|c|c|c|c|}
\hline \hline \multirow{2}{*}{ Point } & \multicolumn{7}{|c|}{ Content, \% wt . } & \multirow{2}{*}{ Phase } \\
\cline { 2 - 9 } & Al-K & Si-K & Ti-K & Cr-K & Mn-K & Cu-K & Ag-L & \\
\hline 1 & 60.6 & 0.6 & 11.0 & 4.6 & 13.1 & 2.0 & 8.0 & $\mathrm{Al}$ \\
\hline 2 & 64.3 & 1.2 & 25.0 & 0 & 0 & 1.4 & 8.1 & $\mathrm{TiAl}_{3}$ \\
\hline
\end{tabular}

\begin{tabular}{|c|c|c|c|c|c|c|c|c|}
\hline \hline \multirow{2}{*}{ Point } & \multicolumn{7}{|c|}{ Content, \% atomic } & \multirow{2}{*}{ Phase } \\
\cline { 2 - 9 } & Al-K & Si-K & Ti-K & Cr-K & Mn-K & Cu-K & Ag-L & \\
\hline 1 & 76.6 & 0.8 & 7.9 & 3.0 & 8.1 & 1.1 & 2.5 & $\mathrm{Al}$ \\
\hline 2 & 78.3 & 1.4 & 17.1 & 0 & 0 & 0.7 & 2.5 & $\mathrm{TiAl}_{3}$ \\
\hline
\end{tabular}




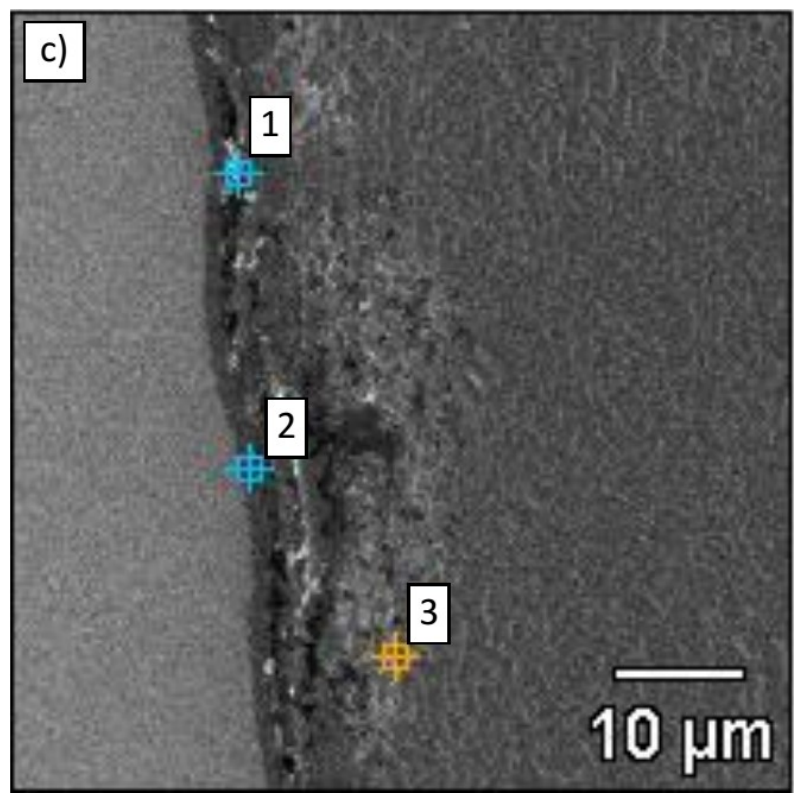

\begin{tabular}{|c|c|c|c|c|c|c|c|c|c|c|c|}
\hline \multirow{2}{*}{ Point } & \multicolumn{5}{|c|}{ Content, \% wt . } & \multicolumn{5}{|c|}{ Content, $\%$ atomic } & \multirow{2}{*}{ Phase } \\
\hline & Al-K & Si-K & Ti-K & Cu-L & Ag-L & Al-K & Si-K & Ti-K & Cu-L & Ag-L & \\
\hline 1 & 29.5 & 1.6 & 24.7 & 1.7 & 42.4 & 52.4 & 2.8 & 24.7 & 1.3 & 18.8 & $\mathrm{TiAl}_{3}$ \\
\hline 2 & 43.4 & 5.1 & 46.1 & 0 & 5.4 & 57.4 & 6.5 & 34.4 & 0 & 1.8 & $\mathrm{Ti}_{5} \mathrm{Al}_{1}$ \\
\hline 3 & 60.0 & 0.6 & 16.8 & 4.0 & 18.6 & 78.5 & 0.8 & 12.4 & 2.2 & 6.1 & $\mathrm{Al}$ \\
\hline
\end{tabular}

Fig. 7. Fragment of the microstructure (on the boundary with titanium-a,b,c) of a diffusion brazed joint made of Grade 2 titanium and AW- 6082 aluminium alloy, using $\mathrm{Ag} 72 \mathrm{Cu}$ filler metal interlayer, at a temperature of $580^{\circ} \mathrm{C}$ and a hold time of $60 \mathrm{~min}$ as well as the local analysis of phases (SEM-EDS)

\section{REFERENCES}

[1] L.A. Dobrzański, Metaloznawstwo opisowe stopów metali nieżelaznych. Wyd. Politechniki Śl., Gliwice (2008) (in Polish).

[2] Joint publication, Poradnik Inżyniera. Spawalnictwo. Vol. 2. WNT Warszawa (2005) (in Polish).

[3] Multi-Author Work, Brazing Handbook. Ed. 5, AWS, Miami, Florida (2007).

[4] M. Schwartz, Brazing Ed. 2, ASM International, Materials Park, Ohio (2003).

[5] Joint publication, Spravočnik po pajkie. Mašinostrojenie, Moskva (2003) (in Russian).

[6] O. Barabaš, J.N. Koval, Struktura i svojstva metallov i splavov. Naukovaja Dumka, Kijev (1986) (in Russian).

[7] T.B. Massalski, Binary alloy phase diagrams. ASM International Materials Park, Ohio (1990).

[8] F. Moller, M. Grden, C. Thomy, F. Vollertsen, Combined laser beam welding and brazing proces for aluminium titanium hybrid structures, Physics Procedia 12, 215-253 (2011).

[9] B.K. Sabokar, W. Zamkov, L.S. Kiriev, Osobiennostiargonowo-dugovoj I diffuzionnoj svarki titana s aluminiem, Avtomatičeskaja Svarka 538 (1), 14-17 (1998) (in Rusian).

[10] J. Wilden, J.P. Bergman, Manufacturing of titanium/aluminium and titanium/steel joints by mean of diffusion welding, Welding and Cuting 3 (5), 285-290 (2004).

[11] J.-G. Luo, V.L. Acoff, Interfacial reactions of titanium and aluminum during diffusion welding, Welding Journal (9), 239-243 (2000).
[12] T. Hamajima, K. Ameyama, A. Fuji, Microstructural change of weld interface in $\mathrm{Ti} / \mathrm{Al}$ friction weld during heat treatment, Journal of Society of Materials Science 44, 1224-1230 (1995).

[13] W.H. Sohn, H.H. Bong, S.H. Hong, Microstructure and bonding mechanism of Al/Ti bonded joint using $\mathrm{Al}-10 \mathrm{Si}-1 \mathrm{Mg}$ filler metal, Material of Science Engineering A355, 231-240 (2003).

[14] A. Al Hazaa, T.I. Khan, I. Haq, Transient liquid phase (TLP) bonding of AL7075 to Ti-6Al-4V alloy, Materials Characterization 61 (3), 312-317 (2010).

[15] M.S. Kenevisi, S.M. Mousavi Khoie, An investigation on microstructure and mechanical properties of A17075 to Ti-6Al-4V transient liquid phase (TLP) bonded joint, Materials and Design 38, 19-25 (2012).

[16] A. Winiowski, Structural and mechanical properties of brazed joints of stainless steel and aluminium, Archives of Metallurgy and Materials 54 (2), 523-533 (2009).

[17] A. Winiowski, Impact of conditions and parameters of brazing of stainless steel and titanium on mechanical and structural properties of joints, Archives of Metallurgy and Materials 52 (4), 593-607 (2007).

[18] A. Winiowski, Mechanical and structural properties of joints of stainless steel and titanium brazed with silver filler metals containing tin, Archives of Metallurgy and Materials 55 (4), 991-1000 (2010).

[19] Z. Mirski, M. Różański, Diffusion brazing of titanium aluminide alloy based on TiAl (g), Archives of Civil and Mechanical Engineering 13, 415-421 (2013). 